\title{
気体収束爆䡛駆動の水中衝撃波による微生物処理に関する研究*
}

宇田川 洋一 ${ }^{* 1}$, 鈴木 実 $^{* 2}$

\section{A Study on Treatment of Microorganisms Using Underwater Shock Waves by Gas Imploding Detonation}

\author{
Yohichi UDAGAWA *1 and Minoru SUZUKI \\ ${ }^{* 1}$ Graduate School of Science, Toho University \\ 2-2-1, Miyama Funabashi, Chiba, 274-8510 Japan
}

Ballast water is used to stabilize an empty ship on the open sea. It often contains various microorganisms such as plankton and bacteria, and causes serious damage to aquatic ecosystems when it is discharged. Ultra-high pressure underwater shock waves were applied to treat those microorganisms. The imploding detonation of propane-oxygen mixture was used to generate the underwater shock waves in a sample holder having an inner diameter of $10.9 \mathrm{~mm}$. We investigated the imploding detonation wave in approximately hemisphere-shaped combustion chamber having maximum inner diameter of $60 \mathrm{~mm}$ and generated underwater shock waves of $100 \mathrm{MPa}$. As microorganisms of the high pressure treatment experiments Artemia salina, Heterosigma akashiwo and Coliform group were used. We could completely treat Artemia salina and Coliform group by 5 shots and Heterosigma akashiwo by 1 shot of the underwater shock wave that maximum pressure was about $100 \mathrm{MPa}$.

Key Words : Environmental Engineering, Underwater Shock Wave, Gas Imploding Detonation, Ultra-High Pressure Treatment, Microorganisms

\section{1. 緒言}

衝撃波や爆轟（デトネーション，Detonation）波を収束させることによって，その収束中心部で高温・高圧状態 が得られることが理論的(1)(2)及び実験的 ${ }^{(3)(4)}$ に示されている．特にデトネーション波の収束については，ほとんど 減衰を伴わないため，衝撃波の場合より効率的に収束させることが可能で，金属材料の成形，加工等の分野での 応用 ${ }^{(5)}$ に関心が持たれている. 我々も実用面への応用を目的として，気体収束デトネーションによって駆動され た管内超高圧水中衝撃波を利用した液体殺菌について検討を行ってきた ${ }^{(6-8)}$.

また，現在，船舶の航行の安定を維持する上で不可欠なバラスト水の給・排水が原因となり，海洋微生物の越 境移動を招き，海洋生態系破壞を引き起こしていることが国際問題となっている ${ }^{(9)(10)}$. 2004 年に国際海事機関

（IMO）は，排出されるバラスト水に厳しい排水基淮を設定し，船舶排水量に対応した段階的な条約の実施を目 指しており，各国に条約の遵守を求めている(11)。これに関連して，世界各国で IMO 基準を満たすバラスト水処 理装置の開発が行われており，いくつかのタイプの処理システムが開発済み，もしくは実用化へ向けた航海実験 を実施している.

これまでに，我々は気体収束デトネーションによって駆動された水中衝撃波を利用した船舶バラスト水中の微 生物処理の可能性について報告した ${ }^{(6)(12)}$ そここで，本報では $100 \mathrm{MPa} レ$ レ゙の衝撃水圧が発生可能な小型衝撃水

\footnotetext{
* 原稿受付 2013 年 8 月 26 日

*1 正員, 東邦大学大学院 理学研究科 環境科学専攻（广274-8510 千葉県船橋市三山 2-2-1）

*2 正員, 東邦大学 理学部 生命圈環境科学科

E-mail: 7612001u@nc.toho-u.ac.jp
} 
圧発生装置を用いて, 船舶バラスト水を想定したサイズの異なる複数の微生物の処理実験を実施し, 死滅率に及 ぼす水中衝撃波の処理回数の影響について調べた結果について報告する.

\section{2. 実験装置及び実験方法}

本実験に使用した装置の概念図を図 1 に，本装置の主要諸元を表 1 に，それぞれ示す．本実験装置は，小型衝 撃水圧発生装置（以下，小型装置）本体と付随するガス供給装置，着火装置，各種計測機器等から構成される. 小型装置本体は，予燃焼室，主燃焼室，試料管の三つに大別できる．主燃焼室と水圧室の間は油圧駆動型の開閉 弁が設置されており, 着火操作前後の短時間開閉するようになっている. また試料管は実験ごとに毎回取り外し, 実験試料を含有する塩水を充填した。

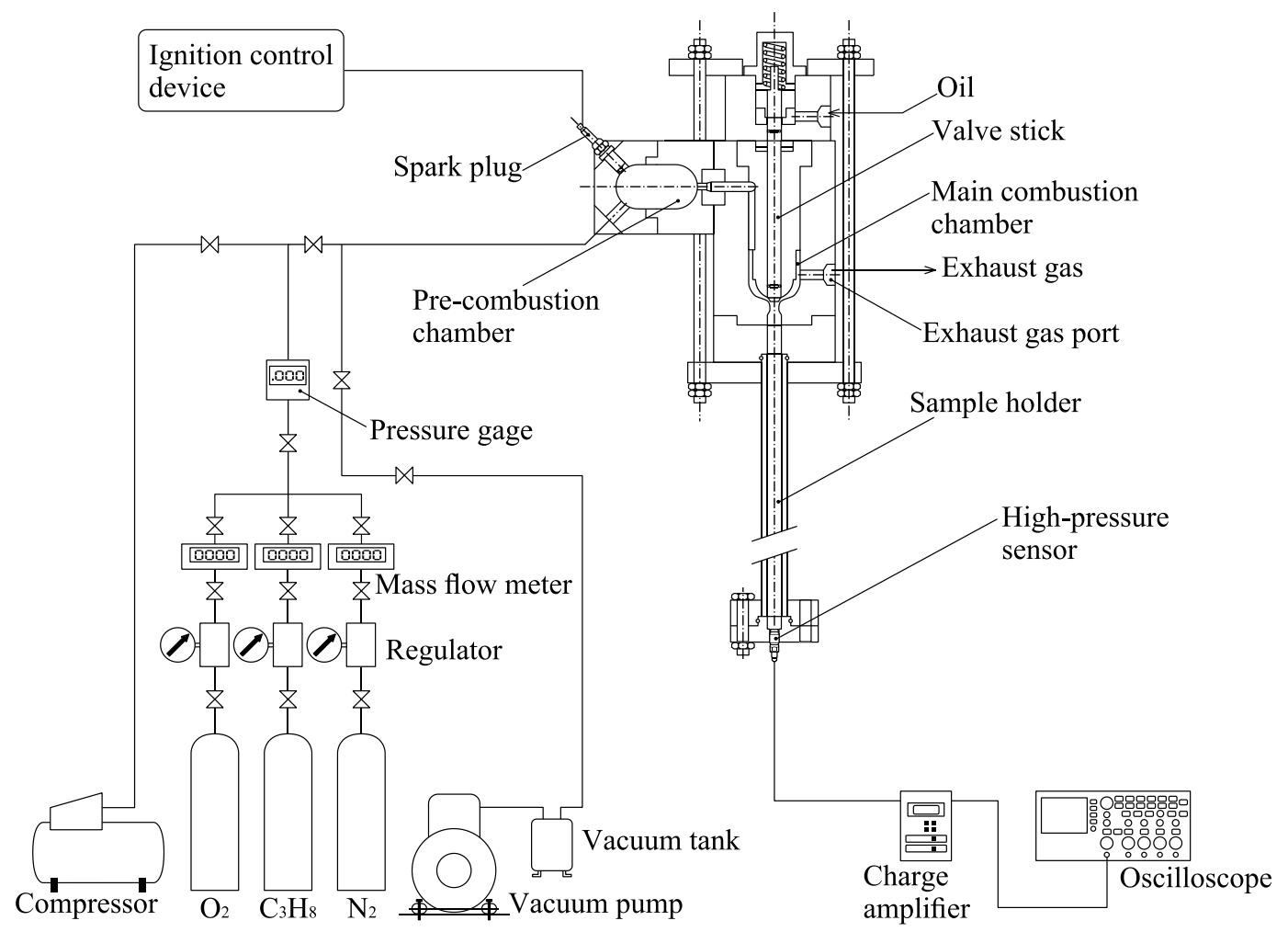

Fig. 1 Schematic diagram of the experimental system

Table 1 Specification of the experimental apparatus

\begin{tabular}{|c|c|c|c|c|c|c|c|}
\hline \multicolumn{2}{|c|}{ Pre-combustion chamber } & \multicolumn{3}{|c|}{ Main combustion chamber } & \multicolumn{3}{c|}{ Sample holder } \\
\hline $\begin{array}{c}\text { Maximum } \\
\text { inner diameter } \\
{[\mathrm{mm}]}\end{array}$ & $\begin{array}{c}\text { Volume } \\
{[\mathrm{L}]}\end{array}$ & $\begin{array}{c}\text { Maximum } \\
\text { inner diameter } \\
{[\mathrm{mm}]}\end{array}$ & $\begin{array}{c}\text { Volume } \\
{[\mathrm{L}]}\end{array}$ & $\begin{array}{c}\text { Inner diameter of } \\
\text { implosion center } \\
{[\mathrm{mm}]}\end{array}$ & $\begin{array}{c}\text { Length } \\
{[\mathrm{mm}]}\end{array}$ & $\begin{array}{c}\text { Inner diameter } \\
{[\mathrm{mm}]}\end{array}$ & $\begin{array}{c}\text { Volume } \\
{[\mathrm{L}]}\end{array}$ \\
\hline 50 & 0.16 & 60 & 0.03 & 5 & 1000 & 10.9 & 0.11 \\
\hline
\end{tabular}

各々の燃焼室内には同一組成の予混合気を同一圧力で充填し，予燃焼室上流端付近に設置した自動車用点火プ ラグ（NGK，BKR5ES-11）を用いて着火した．予燃焼室内では火炎に先行して圧力波が下流側に到達し，主燃焼 室内の未燃予混合気を圧縮することで燃焼直前の圧力の值が初期ガス充填圧の約 3 倍 ${ }^{(13)}$ にまで増圧すると考えら れる (圧力重畳効果 ${ }^{(14)}$ )。予燃焼室を伝播し終えた火炎は，主燃焼室へと伝播するが，その間の誘導路は図 2 に 示すように，下流ほど本数が増加するトーナメント対戦表のような構造となっている．この形状によって，火炎 が主燃焼室の外周部に同時に到達したのち，軸対称性を維持したまま中心部に向かって収束することができる. 最初に 1 本であった通路は倍々に分岐し, 最終的に主燃焼室側では 16 本になる. また，通路幅は主燃焼室側ほど 狭くなる構造になっている，通路断面はカマボコ型となっており，その梁さは通路幅によらず $5 \mathrm{~mm}$ で一定であ 
る.デトネーションが伝播するためには，この誘導路の大きさがセルサイズより大きい必要がある. 今回は燃料 にプロパン，酸化剂に酸素を使用しているが，この混合気においては当量比 1.0 , 初期圧 $50 \mathrm{kPa}$, 初期温度 $293 \mathrm{~K}$ でのセルサイズが $2 \mathrm{~mm}$ を下回っている ${ }^{(15)}$.また，後述のとおり本実験での初期ガス充填圧は $50 \mathrm{kPa}$ をきく上 回っている. 一般にセルサイズは初期圧の上昇に伴って小さくなるので，この誘導路内でデトネーションへと遷 移し伝播することが可能であると考えられる.

主燃焼室は火炎の伝播方向に向かって断面積が徐々に減少する半球状の形状（図 3）になっており,デトネー

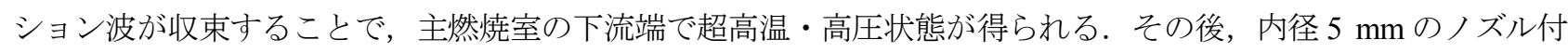
近で水中衝撃波に変換され, 内径 $10.9 \mathrm{~mm}$ の試料管内を衝撃波が数回往復する. なお, 当量比は $1.0 \sim 1.4$ の範囲 内で調整した. また, 水圧室の末端での水中衝撃波の最高圧力の計測には, 水晶圧電式高圧用圧力センサ (KISTLER, 6229A）を使用し，チャージアンプ（KISTLER, 5011B）を介してデジタルストレージオシロスコー プ（Tectronix, TDS2024B）で電圧変化を記録することにより実測した.
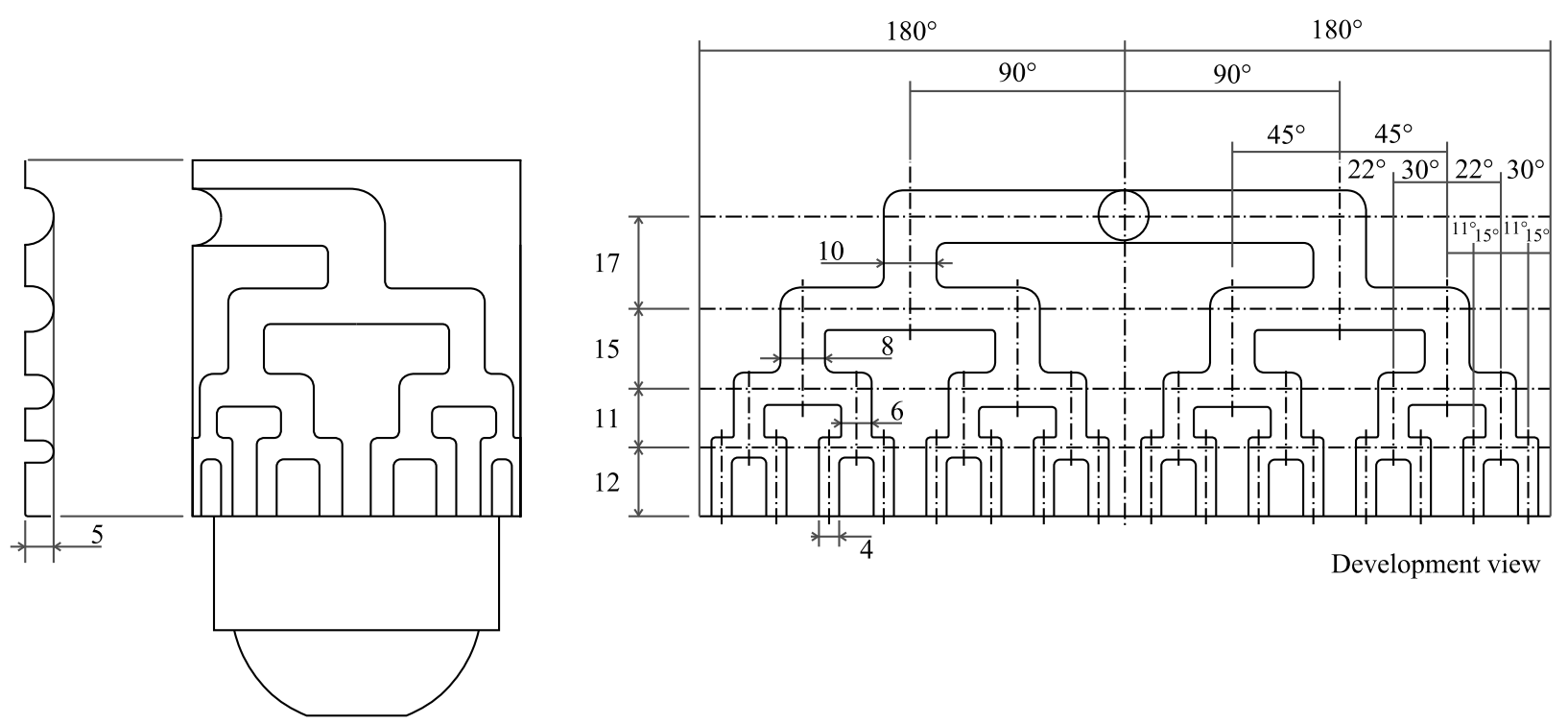

Fig. 2 Sectional view of tournament passage

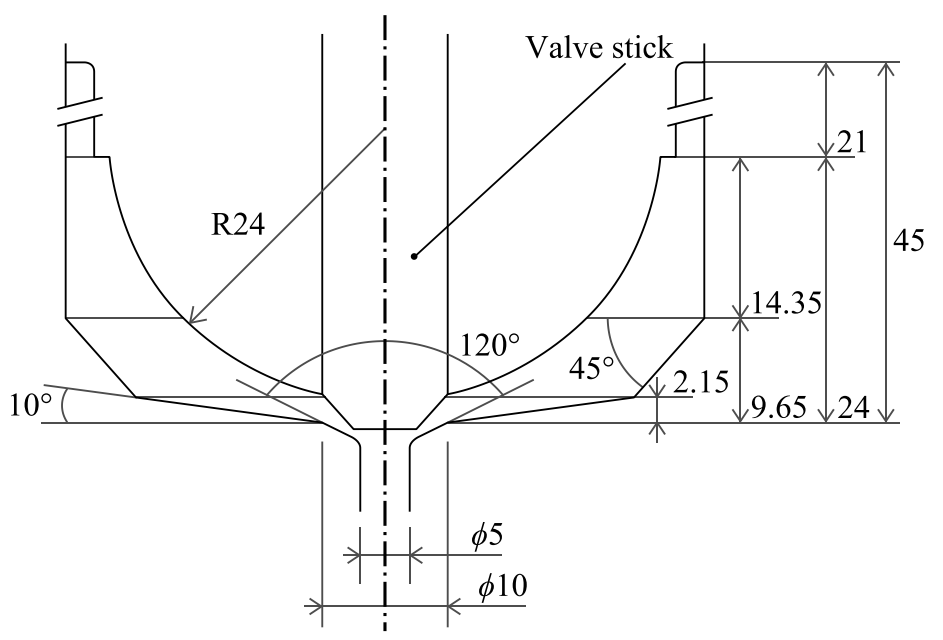

Fig. 3 Sectional view of main combustion chamber

実験試料としては, バラスト水排出基準 ${ }^{(11)}$ に定められている対象生物のうち, 最小サイズ $50 \mu \mathrm{m}$ 以上の生物 (動 物プランクトン）, 最小サイズ $10 \mu \mathrm{m}$ 以上 $50 \mu \mathrm{m}$ 未満の生物（植物プランクトン），大腸菌をそれぞれ模擬する生 物を使用した，具体的には，動物プランクトンにはバラスト水管理システム承認用の陸上試験に適用されるアル テミア (16) (Artemia salina) の幼生, 植物プランクトンとしては赤潮を引き起こすプランクトンの一種であるへテ 
ロシグマ ${ }^{(17)}$ (Heterosigma akashiwo)，及び大腸菌群（大腸菌（Escherichia coli） 及び大腸菌と性質の似ている細菌 を指し, 粪便污染の指標細菌として広く使われている）を用いた。 また, 試料は塩水内に均等に拡散させた. 各々 の試料の塩水中の濃度は実験ごとに偏りがあったが，アルテミアが $1.0 \times 10^{2} \sim 3.0 \times 10^{2} \mathrm{inds} / \mathrm{mL}$ ，へテロシグマが $1.0 \times 10^{8} \sim 2.0 \times 10^{8}$ cells $/ \mathrm{mL}$, 大腸菌群が $1.0 \times 10^{4} \sim 10^{5}$ cells $/ \mathrm{mL}$ の範囲であった.

\section{3. 実験結果及び考察}

\section{$3 \cdot 1$ 水中衝撃波の計測}

今回の処理実験に使用した小型装置は初期ガス充填圧を調整することで, 水中衝撃波の到達圧力の值を変化さ せることが可能である. $0.1 \sim 0.5 \mathrm{MPa}$ の各充填圧で複数回（5～7 回）, 試料管の下流端における水中衝撃波の最 高圧力の測定を行った. その最高圧力の平均值と充填圧との関係を図 4 に示す.

今回の実験の範囲内では，多少のバラつきが認められるものの，充填圧が高いほど，得られる水中衝撃波の最 高圧力の值が高くなる傾向が認められる. 本実験では, $100 \mathrm{MPa}$ レベルの水中衝撃波で複数回処理を行うことで, 微生物に及ぼす水中衝撃波の影響を評価することとした。 よって, この結果から充填圧を $0.5 \mathrm{MPa}$ 近傍に設定し て処理実験を実施した．試料管の下流端に設置した圧力センサによる水中衝撃波の圧力波形を図 5 に示す．ここ でのマイナス方向の振れは, 試料管での振動を圧力センサが検出した結果と考えられる. 同図に示すように数 $\mu \mathrm{sec}$ の間に最高圧力約 $100 \mathrm{MPa}$ ，半值幅約 $3 \mu \mathrm{sec}$ からなる強い圧力波（第 1 波）が現れ，その後も $10 \mathrm{MPa}$ を超える 圧力波が数回到達していることがわかる. なお，第 1 波以降の圧力の絶対值については圧力センサの特性上厳密 な議論はできないが，これらの波は主燃焼室の上流端と下流端（収束中心）の間で高温排ガス中を反射衝撃波が 往復することによって発生したものと考えられる.

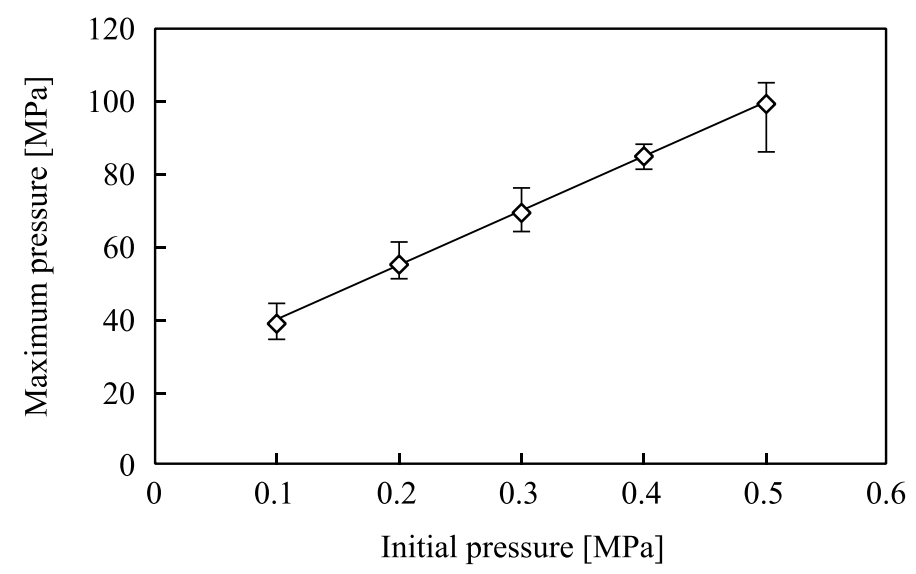

Fig. 4 Effects of initial pressure on the maximum pressure at bottom of the sample holder

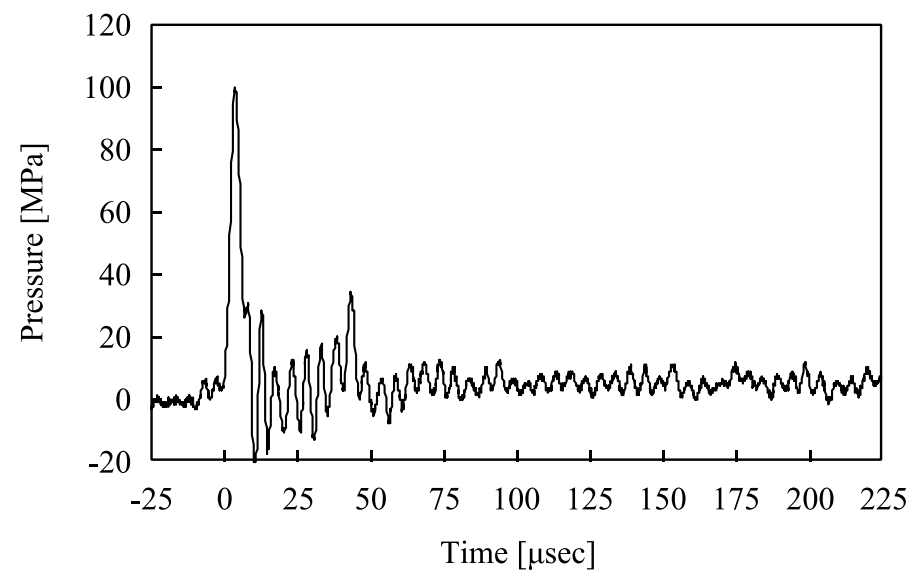

Fig. 5 Pressure histories at the bottom of the sample holder 


\section{$3 \cdot 2$ 処理前後の微生物の変化}

\section{$3 \cdot 2 \cdot 1 \quad$ アルテミア及びヘテロシグマの処理結果}

処理前後でのアルテミア及びヘテロシグマのデジタルマイクロスコープ（KEYENCE，VHX-1000）による観察 結果の写真を, 図 6 及び図 7 にそれぞれ示す。

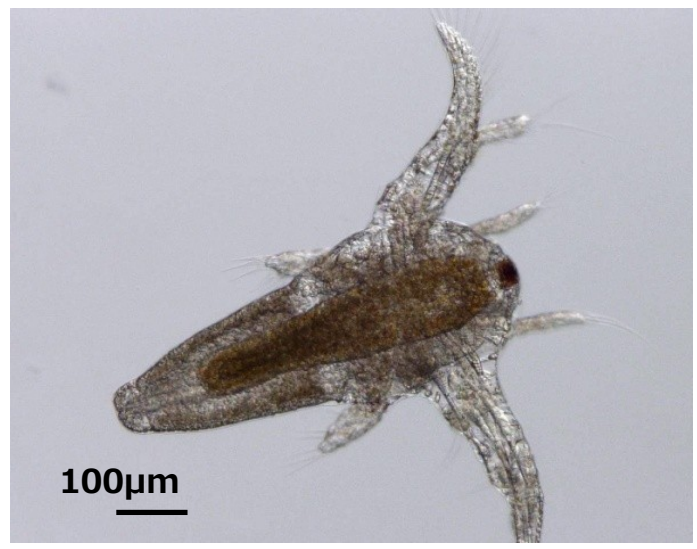

(a) Before shock wave transmission

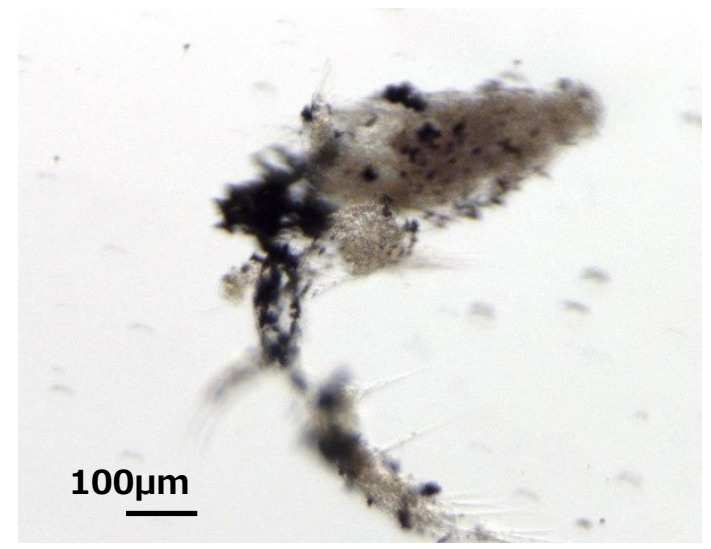

(b) After shock wave transmission

Fig. 6 Digital microscope images of Artemia salina

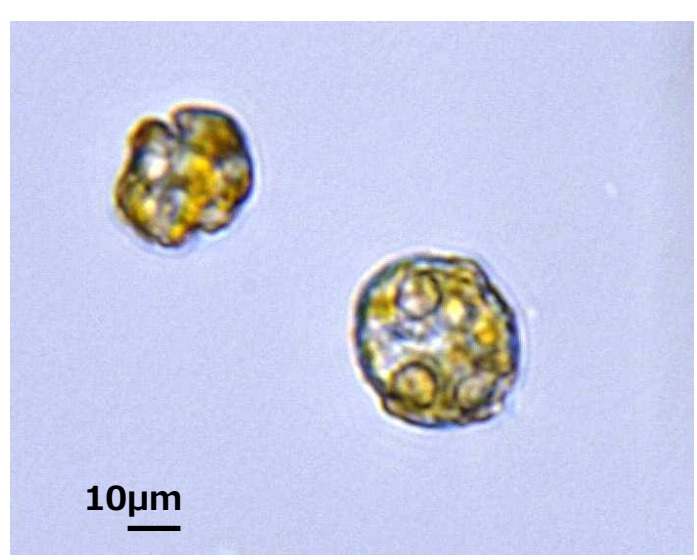

(a) Before shock wave transmission

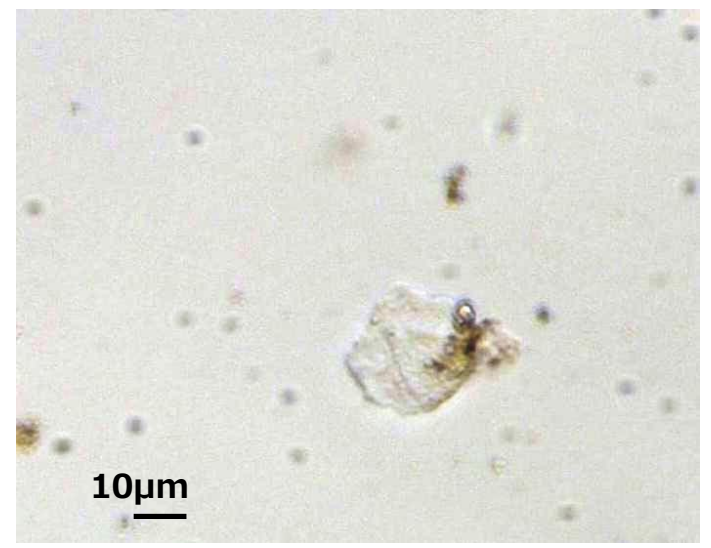

(b) After shock wave transmission

Fig. 7 Digital microscope images of Heterosigma akashiwo

処理後のアルテミアの多くは，図6の(b)のように個体がマクロ的に破壊される顕著な損傷が認められた。これ は，水中衝撃波の透過または反射に伴う急激な圧力変化により，引っ張り，圧縮，せん断等の力が作用したため と考えられる．またへテロシグマの場合には，ほとんどの個体が確認できないほど細かく破壊され，一部の個体 は図 7 の(b)に示すようなマク口的破壊も認められた.

\section{$3 \cdot 2 \cdot 2$ 大腸菌群の処理結果}

大腸菌群の場合には, サイズが小さすぎてデジタルマイクロスコープでの観察が難しいため, 今回はデスオキ シコーレイト寒天培地を用いて大腸菌群の生存個体数 (コロニー数) を調べた. その結果を表 2 に示す. なお CFU とは Colony Forming Unit の略称である. 処理回数が 2 4 回の場合では 20〜4 500 個程度のコロニー数が確認され たが, 処理回数 5 回以上では大腸菌群のコロニーは全く確認されなかった. 
Table 2 Coliform group count

\begin{tabular}{|c|c|c|c|c|c|c|c|c|c|c|c|c|c|c|}
\hline Shot number & \multicolumn{3}{|c|}{2} & \multicolumn{3}{|c|}{4} & \multicolumn{3}{|c|}{5} & \multicolumn{2}{|c|}{6} & \multicolumn{2}{|c|}{8} & Blank \\
\hline $\begin{array}{c}\text { Survived } \\
\text { number } \\
{[\mathrm{CFU} / \mathrm{mL}]}\end{array}$ & 4500 & 1300 & 2400 & 56 & 20 & ND* & ND* & ND* & ND* & $\mathrm{ND}^{*}$ & ND* & $\mathrm{ND}^{*}$ & $\mathrm{ND}^{*}$ & $1.0 \times 10^{4} \sim 10^{5}$ \\
\hline
\end{tabular}

* ND: Not Detectable

\section{$3 \cdot 3$ 死滅率と処理回数との関係}

処理実験終了から 24 時間経過後の試料を対象として, 処理回数と死滅率との関係を調べた結果を, 図 $7 に$ 示す. また，最高圧が $100 \mathrm{MPa}$ レベル以外の場合での処理実験の結果(18)(19)も比較のため載せている. 本実験では，アル テミアについては，処理回数ごとに，同一処理圧力に対して 5 回，ヘテロシグマについては，3回実験を実施し， 処理水からそれぞれ 25 サンプルを採取し，トータルでアルテミアは $5 \times 25=125$ サンプル，ヘテロシグマは $3 \times$ $25=75$ サンプルに対して全数を計数した. 大腸菌については上記のように処理回数が 2，4，5回の実験を 3 回， 6, 8 回の実験を 2 回実施し, それぞれコロニー数を計数した. 死滅率は, 各々の処理後の生存個体（コロニー） 数と, 未処理の場合の個体数との差から算出された死滅個体数を未処理の場合の個体数で除した值から求めた.

死滅の定義としては，バラスト水処理における基準 ${ }^{(20)}$ と同様とした。ここで死滅とは，生物が増殖の可能性を 喪失しているものを指す，具体的には，(1)形態変化，(2)運動性，(3)細胞内活性状態，(4)再成長性のいずれかにつ いて判別を行い死滅の有無を決定する. (1)については個体の体の一部が処理によって破損している場合に死滅と 定める. (2)は運動性を持つ生物のみが対象となるが，運動性を持った生物が処理後に動かなくなった場合は死滅 と定める. (3)は生細胞染色試薬を用いて細胞内活性を確認することによって確認を行う. (4)は処理後の試料を最 適条件下で培養し，生物が増殖するかを確認して生死の判別を行う。このうち，アルテミアとへテロシグマに関 しては(1)及び(2)を，大腸菌に関しては(4)を適用した.

図 8 の(a)及び(c)に示すように, アルテミアと大腸菌は共に処理回数が増えるほど死滅率が増加する傾向にあり， 両方とも 5 回以上で $100 \%$ の死滅率が得られた. よって, 既報 ${ }^{(12)} て ゙$ 報告したように急激な圧力の加減圧による影 響ばかりでなく，水中衝撃波の透過回数が死滅率に影響を与えていることがわかる．また，図 7 の(b)のように， ヘテロシグマについては全ての処理回数において $100 \%$ の死滅率が得られた. 圧力レベルの低い場合ではへテロ シグマ及び大腸菌群の死滅率が比較的低く，処理回数を増やすことで高い死滅率が得られることがわかる.アル テミアに関しては比較的圧力レベルによる違いが大きくはなかったが，処理回数を増加させることでの死滅率の 上昇に関しては同様の傾向が見られた.

衝撃超高圧を加えた微生物の死滅率は，同一の圧力レベルでは，そのサイズが小さいほど低下する(21)ことが示 されている.しかし，一部の值にバラつきがあるものの，今回の実験の範囲内ではそれを確認することはできな かった. よって，微生物に及ぼす水中衝撃波の影響がサイズ以外の条件によっても変化することが考えられる. その理由の一つとして, 先に報告した微生物の体表の物性が考えられる ${ }^{(19)(22)}$. アルテミアの体表は直鎖状の多糖 高分子であるキチン質で構成され，形態を一定に保ち，圧力などの外界からの物理的な力に抵抗し，体内部の環 境を物理的に保護することが可能である. 一方，へテロシグマ及び大腸菌の体表はリン脂質やタンパク質によっ て構成され, これらの生物は体表を通じて物質のやり取りを行うための細孔が存在し, 物理的な力に比較的弱い. 従って，これらの違いが今回の結果に影響を与えたものと考えられる.

\section{4. 結語}

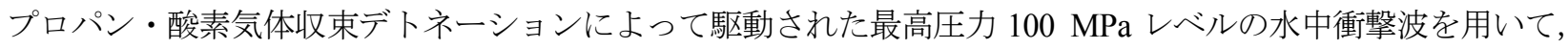
バラスト水を想定したサイズの異なる微生物として，アルテミア，ヘテロシグマ，及び大腸菌群を用いた場合の 水中衝撃波の影響について系統的な処理実験を実施した。これまでに得られた結果は，以下のとおりである.

(1) 収束デトネーション駆動の水中衝撃波により微生物を死滅させることが可能である.

(2) 本実験装置での処理ではアルテミアと大腸菌群は, 水中衝撃波を透過させる回数が多くなるほど死滅率が 増加する傾向が認められた。 
（3）本実験装置での処理ではへテロシグマは，水中衝撃波による処理回数が 1 回で死滅率 $100 \%$ に到達した.

（4）微生物の種類ごとに収束デトネーション駆動の水中衝撃波の影響は異なる可能性がある.

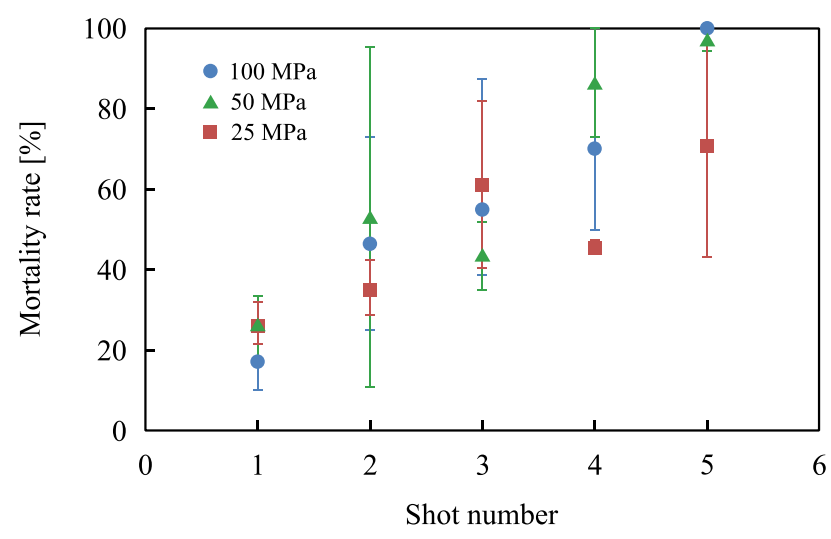

(a) Artemia salina

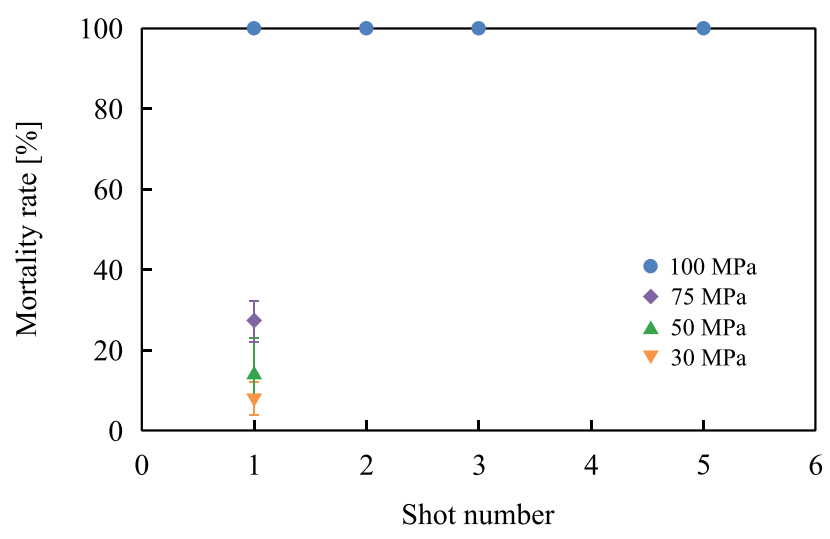

(b) Heterosigma akashiwo

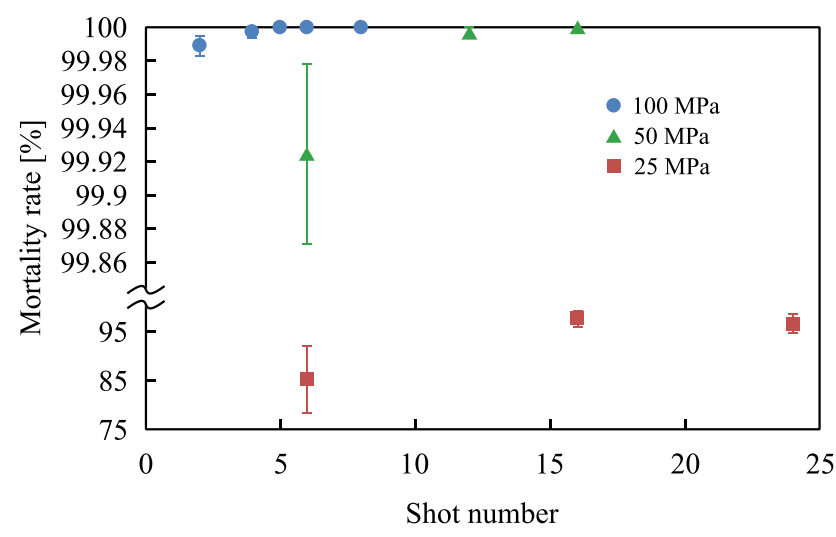

(c) Coliform group

Fig. 8 Experimental results of mortality rate at $24 \mathrm{hr}$ after treatment

\section{文献}

(1) Guderley, G., "Starke kugelige und zylindrische Verdichtungsstöße in der Nähe des Kugelmittelpunktes bzw. der Zylinderachse", Lufffahtfforschung, Bd. 19, Lfg. 9 (1942), pp. 302-312.

（2）位高訓，高山和喜，寺尾邦夫，伊藤勝宏，鈴木実，“収縮するデトネーション波のシミュレーション”，第 68 期日 本機械学会全国大会講演論文集，Vol. B (1990)，pp. 210-212.

(3) Fujiwara, T., Taki, S., and Sugimura, T., "A rotational temperature of oxyacetylene converging detonation", Acta Astronautica, Vol. 1, No. 7-8 (1974), pp. 863-872.

(4) Terao, K., "Experimental Study on Cylindrical and Spherical Implosions", Japanese Journal of Applied Physics, Vol. 22, No. 3 (1983), pp. 446-453.

(5) Honda, A., and Suzuki, M., "Sheet metal forming by using gas imploding detonation", Journal of Materials Processing Technology, Vol. 85, No. 1-3 (1999), pp. 198-203.

（6）鈴木実，“水中衝撃波を用いた船舶バラスト水処理技術の開発”，第 17 回環境工学総合シンポジウム講演論文集 (2007), pp. 202-205.

（7）鈴木実，石川恭央，都築裕康，山口沙耶香，千々石勉，“水中衝撃波を用いたプランクトン処理技術の開発”, 第 19 回環境工学総合シンポジウム講演論文集 (2009), pp. 312-315.

（8）山口沙耶香, 安西竜也, 宇田川洋一, 鈴木実, “超高圧水中衝撃波を用いた大腸菌群の殺菌に関する実験的研究”, 第 21 回廃棄物資源循環学会研究発表会講演論文集 (2010), pp. 605-606. 
(9) Ruiz, G.M., Rawlings, T.K., Dobbs, F.C., Drake, L.A., Mullady, T., Huq, A., and Colwell, R.R., "Global spread of microorganisms by ships", Nature, Vol. 408, No. 6808 (2000), pp. 49-50.

(10) Ruiz, G.M., and Carlton, J.T., Invasive Species (2003), pp. 152-182, Island Press.

(11) 国土交通省総合政策局海洋政策課, “バラスト水管理条約をめぐる国土交通省の取り組み”, 日本水産学会誌, Vol. 73, No. 6(2007), pp. 1150-1154.

（12）宇田川洋一，鈴木実，“アルテミアに及ぼす水中衝撃波の影響（水中衝撃波による微生物処理技術に関する基礎研 究)”，日本機械学会論文集 B 編，Vol. 79， No. 801 (2013)，pp. 804-808.

(13) 石井一洋, 久保田倫弘, 藤本寛幸, 坪井孝夫, 鈴木実, “収束デトネーションを用いたガスエンジン用点火システ ムに関する研究”, 日本機械学会論文集 B 編, Vol. 74, No. 741 (2008), pp. 1183-1190.

(14) F. T. ボダーサ著, 緒方純俊訳, 爆発防止技術の実際 一産業爆発事故の分析と対策一 (1984), pp. 63-64, 海文堂出 版.

(15) GALCIT Explosion Dynamics Laboratory, "Detonation Database”, CALTECH, http://www2.galcit.caltech.edu/detn_db/html/db.html，（参照日 2013 年 11 月 13 日）。

(16) NTS 編，バラスト水規制とバラスト水処理装置の開発事例 (2006), pp. 54-55，エヌ・ティー・エス.

(17) Yamochi, S., "Mechanisms for outbreak of Heterosigma akashiwo red tide in Osaka Bay, Japan", Journal of the Oceanographical Society of Japan, Vol. 39, No. 6 (1983), pp. 310-316.

(18) 鈴木実, 山口沙耶香, “気体収束爆轟によって駆動された水中衝撃波の最高圧力に及ぼす初期力゙ス圧の影響”, 日本 機械学会 2011 年度年次大会講演論文集 (2011), J024035.

(19) 德永久美子, 鈴木実, 松田優美, “超高圧水中衝撃波を受けた赤潮の形態変化に関する研究” 第 23 回廃棄物資源 循環学会研究発表会講演論文集 (2012), pp. 131-132.

(20) 参考文献(16), pp. 42-47.

(21) 藤原和人, 浅川牧夫, 松尾日出男, 広江哲幸, 堀澄人, “衝撃波の微生物細胞膜破壊に及ぼすサイズ効果”, 日本農 芸化学会誌, Vol. 70, No.4 (1996), pp. 465-467.

（22）小野貴美，宇田川洋一，鈴木実，“水中衝撃波による水中微生物の破壊形態に及ぼす体表の性状の影響”，第 23 回 環境工学総合シンポジウム講演論文集 (2013), pp. 263-266. 